\title{
A májbetegségek kialakulásának új szempontjai - különös tekintettel az autophagiára és a mikro-RNS szerepére
}

\author{
Werling Klára dr.
}

Semmelweis Egyetem, Általános Orvostudományi Kar, Belgyógyászati és Hematológai Klinika, Budapest

\begin{abstract}
Az autophagiának fontos szerepe van a sejtmúködés egyensúlyának fenntartásában. Aktivitásának csökkenése kulcsfontosságú különböző májbetegségek kialakulásában és progressziójában. A csökkent autophagia hozzájárul a sejtek elzsírosodásához, az endoplasmaticus reticulum stressz fokozásához és a májbetegség előrehaladásához nem alkoholos eredetű zsírmájban. A krónikus alkoholfogyasztás gátolja az autophagiát. Alfa-1-antitripszin-hiányban az autophagia hozzájárul az endoplasmaticus reticulumban lerakódott kóros fehérjék lebontásához. A hepatitis C- és B-vírusok felhasználják az autophagiát saját replikációjukhoz. A hepatitis C-vírus nem strukturális $5 \mathrm{~A}$ és $5 \mathrm{~B}$ fehérjéi serkentik az autophagosoma-képződést. A mikro-RNS-ek a génexpresszió módosításával szerepet játszanak számos fiziológiás és patológiás folyamatban, így az autophagia szabályozásában is. A mikro-RNS-122 a HCV-replikációban játszik szerepet. HBV-fertőzésben a mikro-RNS-ek befolyásolják a sejthalált, a DNS-károsodást, a vírus rekombinációját és a sejten belüli jelátvitelt. Nem alkoholos eredetű zsírmájban a mikro-RNS-122 a zsír- és szénhidrát-anyagcserén keresztül fejti ki hatását. Alkoholos májbetegségekben a mikro-RNS-ek az oxidatív stressz és a szabadgyök-képződés útján befolyásolják a betegséget. A mikro-RNS-ek hatással vannak az autophagiára, és az autophagia is befolyásolja a mikro-RNS-ek expresszióját. Kölcsönhatásuk megismerése közelebb visz a májbetegségek kialakulásának megértéséhez.
\end{abstract}

Orv Hetil. 2020; 161(35): 1449-1455.

Kulcsszavak: autophagia, mikro-RNS, májbetegségek

\section{New aspects of the development of liver diseases - with special regard to the role of autophagy and microRNA}

Autophagy plays an important role in the homeostasis of the cells and it may be upregulated in response to several types of stresses. Deregulation of autophagy is a key mechanism in the pathogenesis and progression of several liver diseases. Deficient autophagy can contribute to liver steatosis, to endoplasmic reticulum stress and to the progression of non-alcoholic fatty liver disease. Chronic alcohol consumption inhibits autophagy. The accumulated mutant protein in the endoplasmic reticulum can be degraded by autophagy in alpha- 1 -antitrypsin deficiency. Hepatitis $\mathrm{C}$ and $\mathrm{B}$ viruses may exploit the autophagy pathway to promote the own replication. Hepatitis $\mathrm{C}$ virus non-structural protein $5 \mathrm{~A}$ and $5 \mathrm{~B}$ have roles in the induction of autophagosomes. MicroRNAs regulate multiple physiological, pathological functions and autophagy through the modulation of gene expression. MicroRNA-122 is involved in HCV replication. In HBV-infected livers, the microRNA pathways related to cell death, DNA damage, recombination and signal transduction were activated. MicroRNA-122 effects multiple important factors which regulate the lipid and carbohydrate metabolisms in human non-alcoholic fatty liver disease. Oxidative stress and free oxygen radicals generation involved in alcoholic liver diseases development are regulated by microRNAs through different pathways. MicroRNAs control autophagy process and autophagy regulates the expression of microRNA-s. The exploration of their interactions contributes to understanding the development of liver diseases.

Keywords: autophagy, microRNA, liver diseases

Werling K. [New aspects of the development of liver diseases - with special regard to the role of autophagy and microRNA]. Orv Hetil. 2020; 161(35): 1499-1455.

(Beérkezett: 2020. április 6.; elfogadva: 2020. május 4.) 


\section{Rövidítések}

5 '-UTR = 5'-untranslated regions of RNA; ACC2 = acetylCoA carboxylase- 2 ; AE2 $=$ anion exchanger 2 ; AIH = autoimmun hepatitis; $\mathrm{AMPK}=($ adenosine monophosphate-activated protein kinase) adenozin-monofoszfát aktiválta protein-kináz; ATG $=$ autophagy-related genes; $\mathrm{Bcl}-2=\mathrm{B}$-cell lymphoma 2; CFTR-gén = cystás fibrosis transzmembrán regulátor gén; $\mathrm{CHC}=$ krónikus $\mathrm{C}$-vírus-hepatitis; $\mathrm{CMA}=$ chaperon mediálta autophagia; CYP2E1 = citokróm P2E1 enzim; DNS = dezoxiribonukleinsav; $\mathrm{HBV}=$ hepatitis $\mathrm{B}$-vírus; $\mathrm{HbsAg}=(\mathrm{HBV}$ surface antigen) $\mathrm{HBV}$ felszíni antigén; $\mathrm{HCC}=$ hepatocellularis carcinoma; $\mathrm{HCV}$ = hepatitis $\mathrm{C}$-vírus; $\mathrm{HNF} 4$ = hepatocyta nuclear factor 4 ; IFN = interferon; IL = interleukin; $\mathrm{KEAPl}=$ Kelch-like ECH-associated protein-1; LAMP-2A = lysosomeassociated membrane protein type $2 \mathrm{~A} ; \mathrm{LC} 3=$ microtubule-associated protein light chain $3 ; \mathrm{miR}=$ mikro-RNS; $\mathrm{mTOR}=$ (mammalian target of rapamycin) a rapamicin célpontja emlösökben; NAFLD = (non-alcoholic fatty liver disease $)$ nem alkoholos zsírmáj; NASH = (non-alcoholic steatohepatitis) nem alkoholos steatohepatitis; NS5A = nonstrukturális $5 \mathrm{~A}$; PBC = primer biliaris cholangitis; PI3K = phosphatidylinositol-3-kinase PPAR = peroxisome proliferator-activated receptor; RNS = ribonukleinsav; $\mathrm{SHBs}=$ small hepatitis $\mathrm{B}$ surface protein; SREBP $=$ sterol regulatory element binding protein; SQSTMI $=$ sequestron- $1 ;$ TLR $=$ toll-like receptor $; \mathrm{TNF} \alpha=$ tumornekrózisfaktor-alfa; TOMM20 $=$ (translocase of outer mitochondrial membrane 20) mitokondrium külsô membrán transzlokáz-20; $\mathrm{ULKl}=$ uncoordinated 51 -like kinase 1

A májbetegségek jelentős egészségügyi problémát jelentenek világszerte. Évente 1 millió ember hal meg májzsugor, és 1 millió ember vírushepatitis és hepatocellularis carcinoma következtében. 75 millió az alkohollal összefüggő betegek száma, és körükben a májbetegségek vezető helyen állnak. A világon 2 milliárd a kövér emberek és 400 millió a cukorbetegek száma, akik esetében fokozott a nem alkoholos eredetû́ zsírmáj kialakulásának veszélye. A májtranszplantáció a második leggyakoribb szervtranszplantáció [1]. A májbetegségek kialakulásában genetikai, epigenetikai, környezeti tényezók, az immunrendszer reakciója a különböző hatásokra, a felszabaduló citokinek, az apoptózis, az oxidatív és endoplasmaticus reticulum stressz, a bélbaktériumok összetételének megváltozása, a bél-máj tengely játszik szerepet. Az autophagia részt vesz az anyagcsere-folyamatokban, az energia-egyensúly fenntartásában, a károsodott sejtalkotórészek, fehérjék lebontásában; igazolták szerepét májbetegségekben. A mikro-RNS-ek a génexpresszió módosításával szerepet játszanak a biológiai folyamatokban, az autophagia szabályozásában és több betegség, így a májbetegségek kialakulásában. Ugyanakkor az autophagia is hatással van a miR-ek expressziójára. Kölcsönhatásuk feltárása és megértése közelebb visz a májbetegségek kialakulásának megértéséhez. A cikk ennek a témának az eredményeit foglalja össze.

\section{Autophagia}

Az autophagia a sejtekben az elöregedett, meghibásodott, nem funkcionáló sejtalkotók, makromolekulák emésztését végzi. Az autophagia során membrán veszi körül a lebontandó anyagot, így jön létre a phagophor. A kettős membrán záródásával alakul ki az autophagosoma, mely külső membránjával kapcsolódik a lysosomához. A keletkezett autophagolysosomában a szállított elemek savas hidrolázok segítségével lebomlanak. Az autophagosoma képződésének 3 fó lépcsője van: a kezdeti szakaszban az ULKl-komplex játszik szerepet, a második a Beclin-1 és a PI3K segítségével zajlik. A harmadik szakaszban az izolációs membrán megnyúlása következik be, amiben kulcsszerepe van az LC3-fehérjének (1. ábra). Az önemésztés során keletkezett aminosavak és a kis molekulák visszajutnak a citoplazmába, hogy újra hasznosuljanak, és energiát szolgáltassanak a sejtnek [2].

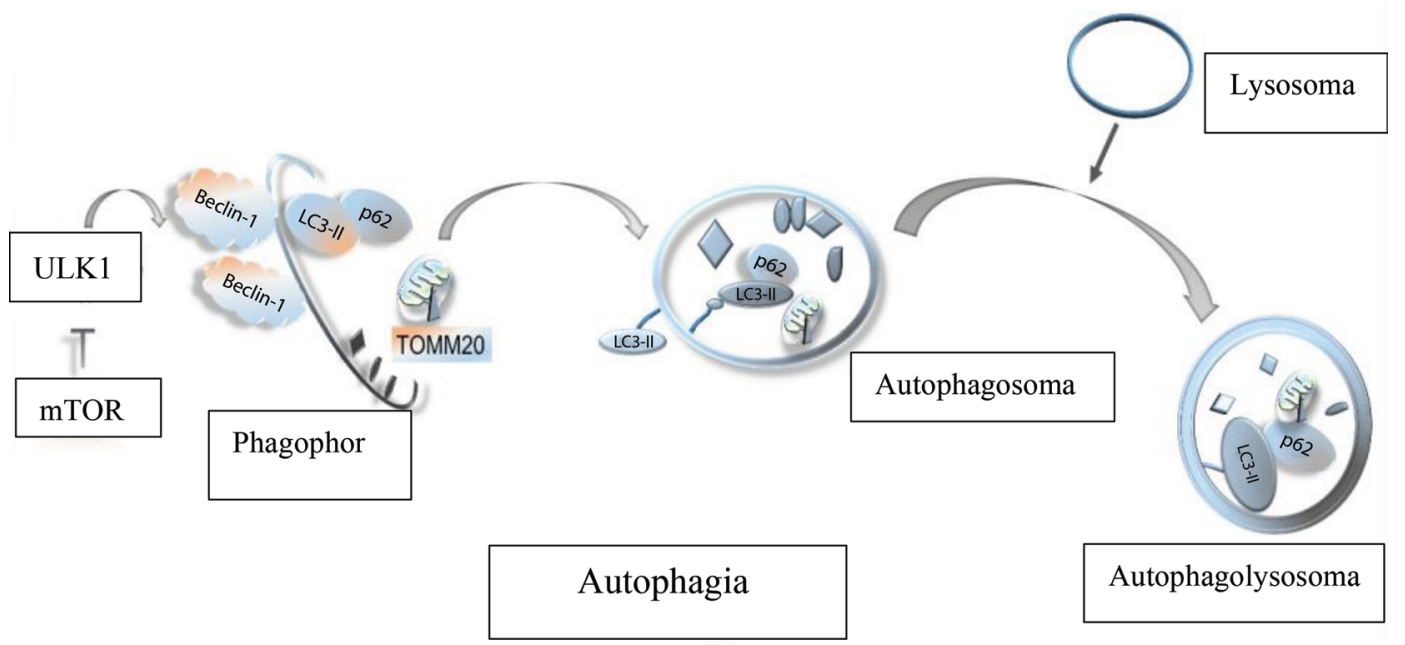

1. ábra

\footnotetext{
Az autophagia folyamata

LC3 = microtubule-associated protein light chain 3; $\mathrm{mTOR}=$ a rapamicin célpontja emlősökben; TOMM20 = mitokondrium külső membrán transz lokáz-20; ULKl= uncoordinated 51 -like kinase 1
} 
Az elmúlt évtizedek kutatásai rámutattak az autophagia jelentőségére a különböző májbetegségek kialakulásában. Az autophagia részt vesz a sejtek növekedésében, differenciálódásában, hozzájárul a sejtmúködés egyensúlyának fenntartásához, a sejtalkotók újraképzéséhez, védi a sejteket a stresszfaktoroktól, segíti az antigénprezentációt és a mikrobák, vírusok eliminálását [2-4].

Az autophagiának három formája van: macroautophagia, microautophagia és chaperon mediálta autophagia, melyek funkciójukban és a lysosomához jutás módjában különböznek egymástól. Macroautophagia során a hoszszú élettartamú fehérjék és sejtalkotók bomlanak le a lysosomákban [2], ennek során kettős membrán veszi körül a citoplazma egy részét. Az autophagosoma ezt követően egyesül lysosomával, és a szállított anyagok a keletkezett autolysosomában bomlanak le. A chaperon mediálta autophagiánál (CMA) a chaperon Hsc70 felismeri a megfelelő pentapeptidmintával rendelkező fehérjéket, és elszállítja őket a lysosomákhoz, ahol azok lebomlanak [5]. A microautophagiánál a sejtalkotók a lysosomalis membrán betüremkedésével kerülnek a lysosomákba. A szelektív autophagiák az anyagcsere-folyamatokban játszanak szerepet. Ilyen a mitophagia, a pexophagia, a lipophagia, a glycophagia és a sequestron-1 (SQSTMI) mediálta Kelch-like ECH-asszociált protein-1 (KEAPl-) lebontás [3]. A mitophagia során a károsodott mitokondriumok eliminációja történik. Ennek a folyamatnak fontos szerepe van az oxidatív stressz káros hatásainak csökkentésében, a sejtek egyensúlyának fenntartásában $[6,7]$. A lipophagiát a sejtekben levő lipidcseppek lysosomákhoz történő szállítása és lebontása jellemzi. Glycophagia alatt az autophagosomák a glikogéntartalmú granulumokat glükózzá alakítják. A SQSTM1 mediálta KEAPl-degradációt metabolikus, oxidatívstressz-hatások indítják el [3].

\section{Az autophagia szerepe a májbetegségekben}

\section{Nem alkoholos eredetü zsirmáj}

A normális zsíranyagcserében a lipophagia játszik fontos szerepet, mely a lipidcseppeket eljuttatja a lysosomákhoz, ahol azok zsírsavakra bomlanak [8]. Nem alkoholos eredetű zsírmájban az autophagolysosoma-képződés gátolt, az autophagosoma nem tud kapcsolódni a lysosomához, így a lebontás elmarad. A felhalmozódott triglicerid, a szabad zsírsavak, a lipotoxikus hatások, az inzulinrezisztencia, az oxidatív stressz gátolják az autophagiát, és ezáltal hozzájárulnak a zsírmáj kialakulásához [9]. Túlsúlyos betegek májában fokozódik az mTOR aktivitása, ami gátolja az autophagiát [10]. Az autophagiát fokozó szerek - mint a karbamazepin, rapamicin enyhítik a steatosist [3]. A hepatocytákban a csökkent autophagia miatt a károsodott mitokondriumok a citoplazmában felhalmozódnak, fokozódik az oxidatív stressz, és ez a SQSTMI mediálta KEAPl-degradációt növeli, melynek szerepe van a káros hatások kivédésében.
Amennyiben az antioxidáns-kapacitás kimerül, fokozódik a lipidperoxidáció, a proteinoxidáció, és DNS-károsodás jön létre [11]. A csillagsejtekben (stellate cells) zajló autophagia ellentétes hatású a májsejtekéhez képest, mert elősegíti a csillagsejtek myofibroblastokká alakulását, a kötőszövet átépülését és a betegség progresszióját [12].

\section{Virushepatitisek}

A hepatitis C-vírus (HCV) és a hepatitis B-vírus (HBV) megváltoztatják és a maguk hasznára fordítják az autophagiát [13]. Vizsgálatok azt mutatták, hogy a HCVfertőzött májsejtekben fokozódik az autophagia, ami független a genotípustól [14]. A HCV felhasználja az autophagiát a saját replikációjához és az életciklusához. A HCV-indukált autophagia képes gátolni a veleszületett immunválaszt és ezáltal az interferon (IFN) termelődését is. Mindezek hozzájárulnak ahhoz, hogy a HCV-fertőzés fennmaradjon, és krónikus hepatitis alakuljon ki [15].

Sejtkultúrán végzett vizsgálatok szerint az autophagiában fontos szerepet játszó fehérjék - az ATG7, a Beclin-1, az ATG12 és az ATG5 - szükségesek a vírusreplikáció elindításához [14]. Az autophagosomák felületén kimutatott nonstrukturális 5A (NS5A) és NS5B vírusfehérjéknek az autophagia indukciójában lehet szerepük [16].

A HBV fokozza az autophagosoma-képződést a májsejtekben, és gátolja az autolysosomák lebontását. A $\mathrm{HBx}$ fontos szerepet játszik az autophagia fokozásában, kötődik a PI3KIII-hoz (phosphatidylinositol-3-kinase III-as osztályhoz tartó fehérje), mely az autophagia fontos szabályozója, valamint serkenteni a Beclin-1 transzkripcióját [17]. A HBV kis felületi fehérje $(\mathrm{SHBs}=$ small hepatitis B surface protein) az LC3-fehérjén keresztül fokozza az autophagiát [18].

\section{Alkoholos májbetegségek}

Az autophagia védőszerepet játszik az alkohol okozta májkárosodásokkal, elzsírosodással szemben. Az alkohol lebontása során keletkezett szabad gyökök, reaktív acetaldehid, zsírsavészterek, foszfatidil-etanol szerepet játszanak a szövetkárosodás kialakulásában [2]. A hepatocytákban a szelektív autophagia különböző formái segítenek az oxidatív stressz és a májkárosodás megelőzésében. Az alkoholos májbetegségekben a mitophagiának és a lipophagiának egyaránt fontos szerepe van [19]. Krónikus alkoholfogyasztás során csökken a májsejtekben az autophagia, amiben szerepe van az adenozin-monofoszfát aktiválta protein-kináz (AMPK-) aktivitás csökkenésének - ez az mTOR-útvonalon keresztül az autophagia csökkenését idézi elő. A lysosomák pH-értéke megemelkedik, aminek következtében megváltozik a lysosomalis enzimek mozgása [20]. Az autophagia részt vesz a hibás fehérjék eltávolításában; amennyiben múkö- 
dése csökken, ezek a sejt számára kóros fehérjék felszaporodnak a májsejtekben. Ezt mutatják a Mallory-testek, melyek a csökkent fehérjelebontás következményei, és kimutathatók az autophagiás vakuólumokban [4].

\section{Alfa-1-antitripszin-biány}

A betegséget a SERPINAl-gén mutációja okozza, mely az alfa-1-antitripszint kódolja $[3,21]$. Ez egy proteáz enzim, mely gátolja a neutrofil elasztázt, és védelmet nyújt a proteolitikus hatásokkal szemben. A mutáció következtében kóros fehérjék szaporodnak fel, melyek a tüdőszövet károsodásához és májbetegséghez vezetnek [21]. Alfa-1-antitripszin-hiányban szenvedő betegek májsejtjeiben fokozódik az autophagia, megnő az autophagosomák száma, aminek fontos szerepe van az endoplasmaticus reticulum stressz során felhalmozott fehérjék lebontásában. A szelektív autophagiának ezt a formáját ER-phagiának nevezik [22]. Az autophagiát fokozó flufenazin gyógyszer kipróbálása a betegség kezelésére folyamatban van [23].

\section{Hepatocellularis carcinoma (HCC)}

$\mathrm{Az}$ autophagiának ellentmondásos szerepe van a HCC kialakulásában és progressziójában [24]. A daganatképződés korai szakaszában az autophagia gátolja a sejtek malignus átalakulását. A Beclin-1 gén deletióját igazolták HBV talaján kialakult HCC-ben. Egereken végzett kísérletek során több, autophagiát szabályozó gén deletióját találták jó- és rosszindulatú májdaganatokban. Az UVRAG-gén deletiója hajlamosított HCC kialakulására, az ATG5 és ATG7 deletióját májadenomákban igazolták. Az autophagiának szerepe van a károsodott mitokondriumok és a felszaporodott fehérjék lebontásában, és ezzel hozzájárul a máj homeosztázisának fenntartásához és a tumorok kialakulásának megelőzéséhez. Az autophagia folyamatának károsodása fokozza az oxidatív stresszt, a genominstabilitást, és növeli a tumor kialakulásának veszélyét.

A már kifejlődött daganatokban ezzel ellentétben az autophagia szerepet játszik a tumorok progressziójában. A gyorsan növekvő daganatoknál a tumor egyes részeinek vérellátása nem jó, oxigén- és tápanyaghiány lép fel. Ezeken a területeken az autophagia fokozódik, és ezzel segíti a sejtek túlélését, hozzájárul a tumoros sejtek életben maradásához hypoxia, oxidatív stressz és kemoterápia mellett is [24].

\section{Egyéb májbetegségek}

Saját vizsgálatainkban azt találtuk, hogy magasabb az LC3-, a p62-szint autoimmun hepatitisben a CHC-hez képest. Az eredmény arra utal, hogy az autophagosomaképződés fokozódik AIH-ban, de a lysosomalis fehérje lebontása elmarad. A mitokondrium károsodására utaló magasabb TOMM20-szint korrelált a gyulladás, sejtelhalás mértékével. Véleményünk szerint a felhalmozódott, sérült mitokondriumok indukálják az autophagiát, ám mivel az nem fut végig, a sérült mitokondriumok eltávolítása elmarad, ami fokozza a májkárosodást [7].

Primer biliaris cholangitisben az autophagia csökken, erre utal a gátolt LC3-expresszió és a magasabb p62szint [25]. Az autophagia gátlásában valószínúleg a hidrofób epesavak okozta endoplasmaticus reticulum stressz játszik szerepet.

Cystás fibrosisban a CFTR-gén mutációja a transzglutamináz-2 enzim aktivációjához vezet, ami a Beclin-1 és így az autophagia gátlását idézi elő. Wilson-kórban az autophagia fokozódik, de aktivitása nem elegendő ahhoz, hogy a felszaporodott réz okozta citotoxicitást megakadályozza [26].

\section{A mikro-RNS szerepe a májbetegségekben}

Az 1993-ban felfedezett mikro-RNS-ek nem kódoló, 18-24 nukleotidból álló RNS-ek, melyeknek szerepük van számos élettani és kóros folyamat szabályozásában. Génexpresszió módosításán keresztül gátolják a cél-RNS transzlációját, vagy fokozzák a lebomlását [27, 28]. Eddig 2000 mikro-RNS-t mutattak ki emberben, melyek több mint $60 \%$-a a proteineket kódoló géneket szabályozza [29]. Az elmúlt 20 évben igazolták szerepüket a májban a gyulladás, a fibrosis és a cirrhosis kialakulásában (1. táblázat) [7, 27, 30-32].

\section{Virushepatitisek}

A mikro-RNS-122-nek fontos szerepe van a HCV replikációjában, gátlása csökkenti a vírus szaporodását. A HCV-RNS az 5'-UTR végéhez kötődve növeli a vírusreplikációt, és valószínú, hogy befolyásolja a vírus lebomlását is [27, 33]. HCV-fertőzöttek vérében magasabb a miR-122, a miR-155, a miR-34a, a miR-21, a miR-146a és a miR-125b szintje. A megváltozott mikroRNS-expressziónak HCV-fertőzésben hatása van az immunreakcióra, az antigénprezentációra, a sejtciklus szabályozására, a zsíranyagcserére és ezáltal a májbetegség kialakulására [27, 34].

Vizsgálatainkban azt találtuk, hogy krónikus C-vírushepatitisben a miR-101-expresszió jelentősebb a krónikus autoimmun hepatitishez képest. A miR-224 korrelált a steatosis mértékével. Statisztikai különbséget találtunk a miR-155-expresszióban az Fl- és F4-stádiumú fibrosis között $(\mathrm{p}<0,05)$, ami azt mutatja, hogy a miR-155-expresszió korrelál a fibrosis mértékével krónikus C-vírushepatitisben $(\mathrm{r}=0,56 ; \mathrm{p}<0,01)$ [7].

HBV-fertőzésben számos mikro-RNS expressziója megváltozik, melyek befolyásolják a sejthalált, a DNSkárosodást, a sejten belüli jelátviteli rendszert, a vírus rekombinációját. A szérum miR-122-expressziója fokozódik HBV-fertőzésben, és korrelál a HBsAg-szinttel. HBV okozta májbetegségekben összefüggést találtak a 
csökkent expressziója és a gyulladás, kötőszövet-átépülés, steatosis, a HCC kialakulása között. Felvetődött annak lehetősége, hogy a miR-122 szintje alkalmas lehet a vírushordozók, valamint a lassú és a gyors progressziójú májbetegség elkülönítésében [35].

\section{Alkoholos májbetegségek}

Az alkohol metabolizmusa során felszabaduló vegyületek direkt toxikus hatása mellett az alkoholos májbetegség kialakulásában fontos szerepet játszik a bélnyálkahártya fokozott áteresztóképessége, melyet az acetaldehid idéz elő [36]. A bakteriális lipopoliszacharidok a májba jutva a toll-like receptor 4-hez (TLR4) kötődnek, a tumornekrózisfaktor-alfa (TNF $\alpha$ ) és más, gyulladást elősegítő citokinek segítségével aktiválják a Kupffer- és a csillagsejteket. A mikro-RNS-ek részt vesznek a szabadgyök-képződés és az oxidatív stressz szabályozásában, a macrophagok aktivációjában [37], a sejtek közötti kommunikációban, az exosomák szekréciójában [38]. Az alkohol metabolizmusában részt vevő CYP2El-enzimek expresszióját a miR-214, a gyulladást a miR-497 befolyásolja [39]. Míg a miR-34a és a miR-200a serkentik a hepatocytaapoptózist, addig a miR-21 gátolja azt alkoholos májbetegségekben [36]. Mindemellett az alkohol számos mikro-RNS expresszióját megváltoztatja (1. táblázat) $[27,36]$.

\section{Nem alkoholos eredetü zsírmáj}

A NAFLD kialakulásában szerepet játszanak genetikai, epigenetikai tényezők, lipotoxinok, az endoplasmaticus reticulum stressz, az autophagia, a bél-máj tengely és a toxikus epesavak [40]. A mikro-RNS-ek az anyagcserefolyamatokra kifejtett hatásuk révén befolyásolják a be-

1. táblázat | Keringő mikro-RNS-ek májbetegségekben [27, 36]

\begin{tabular}{|c|c|c|}
\hline Májbetegség & mikro-RNS & Expresszió \\
\hline $\begin{array}{l}\text { Alkoholos } \\
\text { májbetegségek }\end{array}$ & $\begin{array}{l}\text { miR-122 (akut alkohol, microvesicu- } \\
\text { laris steatosis) } \\
\text { miR-122, miR-155 (krónikus alkohol, } \\
\text { macrovesicularis steatosis) } \\
\text { miR-192, miR-30a, miR-27a, } \\
\text { miR-182, } \\
\text { miR-103, miR-107 }\end{array}$ & $\begin{array}{l}\text { Fokozódik } \\
\text { Fokozódik } \\
\text { Fokozódik }\end{array}$ \\
\hline Hepatitis C & $\begin{array}{l}\text { miR-122, miR34a, miR-155, } \\
\text { miR-125b } \\
\text { miR-146a, miR-21 }\end{array}$ & Fokozódik \\
\hline Hepatitis B & miRl92, miR-122 & Fokozódik \\
\hline $\begin{array}{l}\text { Nem alkoholos } \\
\text { eredetú zsírmáj }\end{array}$ & miR-122, miR-34a, miR-33, miR-24 & Fokozódik \\
\hline $\begin{array}{l}\text { Hepatocellula- } \\
\text { ris carcinoma }\end{array}$ & $\begin{array}{l}\operatorname{miR}-199 \mathrm{a} / \mathrm{b}-3 \mathrm{p}, \mathrm{miR}-21, \mathrm{miR}-16 \text {, } \\
\text { miR-223, miR-885-5p } \\
\text { miR-29 }\end{array}$ & $\begin{array}{l}\text { Fokozódik } \\
\text { Csökken }\end{array}$ \\
\hline
\end{tabular}

$\operatorname{miR}=$ mikro- $\mathrm{RNS}$ tegség kifejlődését. A miR-122 szintje nő a szérumban, és csökken a májszövetben, ami hatással van a zsíranyagcserére, befolyásolja az acetyl-CoA-carboxylase-2 (ACC2) és a szterolszabályozó elemet kötő fehérje (sterol regulatory element binding protein, SREBP) hatását, növeli a zsírsavak oxidációját, és csökkenti a sejtekben a trigliceridlerakódást. A miR-122 gátolja a glikogénszintézist, fokozza a glikolízist, ezáltal befolyásolja a szénhidrát-anyagcserét is [41]. NAFLD esetében a miR-34a expressziója fokozódik mind a szérumban, mind a májszövetben. A PPAR $\alpha$-ra és a szirtuin-1-re kifejtett hatásán keresztül csökkenti a zsírsavak lebontását, elősegíti a zsírmáj kialakulását, és a hepatocyta nuclear factor 4-en (HNF4) keresztül befolyásolja a zsíranyagcserében részt vevő gének transzkripcióját [42]. A miR-33 szintje emelkedett a májszövetben és a keringésben, elsősorban nem alkoholos eredetú steatohepatitisben (NASH). A májsejtekben szabályozza a koleszterin és a zsírsavak metabolizmusát. A miR-24 szintje a fiziológiás körülményekhez képest stressz hatására fokozódik. NASH-ben jelentősen emelkedett értéket mértek a májban és a szérumban egyaránt. Befolyásolja a koleszterin-, a trigliceridmetabolizmust és a gyulladást [42].

A NAFLD gyógyszeres kezelése még nincs megoldva. A miR-ek a célpontjai lehetnek a betegség kezelésére alkalmas gyógyszer kifejlesztésének. Jelenleg ilyen irányú vizsgálatok folyamatban vannak [36].

\section{Hepatocellularis carcinoma}

A mikro-RNS-ek részt vesznek a sejtciklus, a sejtproliferáció szabályozásában, és expressziójuk megváltozása hatással van a daganatok kialakulására. A miR-199a/b-3p gátolja a HCC növekedését, összefüggést találtak az alacsonyabb szint és a rosszabb prognózis között. A miR151 elősegíti a tumorsejtek terjedését, és így hozzájárul a metasztázisképződéshez. A miR-221-nek szerepe van a sejtciklus szabályozásában és a DNS-károsodás kialakulásában, gátlása növeli a túlélést. A miR-29 hatással van azokra a génekre, melyek szerepet játszanak az angiogenezisben, a tumor terjedésében, az áttétképződésben, és befolyásolja más, nem kódoló RNS-ek expresszióját, megsokszorozva azok hatását; szintje HCC-ben csökken. A miR-26-nak védőhatása van a májtumor kialakulásával szemben. A miR-122 csökkent expressziója öszszefüggést mutat az áttétképződéssel [27]. Egyéb mikro-RNS-ek expressziójának változását HCC-ben az 1. táblázat tünteti fel.

Magyar kutatók vizsgálták HCC-betegekben a szorafenibkezelés előtti mikro-RNS-szinteket és azok összefüggését a kezelés utáni túléléssel. Kapcsolatot találtak a magas miR-224-expresszió és a progressziómentes túlélés, valamint a hosszabb túlélési idő között. Magasabb miR-214-expressziót észleltek az 5 cm-nél kisebb tumoroknál, és jelentősebb miR-17-5-expresszió mellett jobb volt a betegek általános állapota [43]. 


\section{Egyéb májbetegségek}

A miR-506 fokozottan expresszálódik a cholangiocyták felszínén, és befolyásolja a membrántranszport-folyamatokat. Primer biliaris cholangitisben (PBC) azt találták, hogy a gyulladást elősegítő citokinek fokozzák az aktivitását. A miR-506 csökkenti az anion exchanger 2 (AE2) fehérje expresszióját, melynek a bikarbonátkiválasztásban van szerepe, valamint fokozza a gyulladást, a kötőszövet-átépülést, az oxidatív és endoplasmaticus reticulum stresszt, csökkenti a sejtproliferációt és -adhéziót, érzékenyíti a sejteket az apoptózisra [44]. A csökkent miR-122-, miR-16a- és a magasabb miR-328-, miR299-5p-szintek PBC-ben befolyásolják a sejtproliferációt, az apoptózist, a gyulladást, az oxidatív stresszt [27].

Saját munkánkban négy mikro-RNS expresszióját vizsgáltuk krónikus C-vírus-hepatitisben (CHC) és autoimmun hepatitisben (AIH). Nem találtunk szignifikáns különbséget a miR-224-, miR-155- és miR-204-expreszszióban a két betegség között, ugyanakkor a miR-101 expressziója jelentősebb volt CHC-ben [7]. Tu és mtsai igazolták a miR-143 védőszerepét AIH-ban, csökkenti a gyulladást és a kötőszövet-átépülést [45].

\section{A mikro-RNS és az autophagia kölcsönhatása}

Kimutatták, hogy az autophagiát transzkripciós úton kis, nem kódoló mikro-RNS-ek képesek szabályozni, amelyek a mikro-RNS-ekkel történő komplementer bázispárosítás révén befolyásolják a gének expresszióját. Ugyanakkor az autophagia is szabályozza a mikro-RNS-ek expresszióját [46].

A mikro-RNS-ek hatását az autophagiára a leggyakrabban tumorokban vizsgálták. A miR-375 gátolja az autophagiát az ATG7-gén hatásának módosításán keresztül, szintje csökken HCC-ben és hypoxiás körülmények között, tumorszuppresszor hatású. A miR-199a-5p szintén a géneken keresztül gátolja az autophagia folyamatát. Ciszplatinnal kezelt HCC-betegeknél a gyógyszer-rezisztencia összefüggést mutatott a miR-199a-5pexpresszió csökkenésével, amit az autophagiára kifejtett hatásával magyaráztak. A miR-101 csökkenti az autophagiát, tumorszuppresszor hatású, expressziója HCC-ben csökken [46].

$\mathrm{Az}$ autophagia is befolyásolhatja a mikro-RNS hatását. HBV talaján kialakult HCC-ben fordított arányt találtak az autophagia aktivitása és a miR-224 szintje között. Kimutatták, hogy az autophagia részt vesz a miR-244 lebontásában, és így gátolja a májtumor kialakulását [46].

Alkoholos májbetegségekben a miR-26a fokozza az autophagiát, és ezzel hozzájárul a májkárosodás kivédéséhez [47]. Ebben a betegségben igazolták, hogy a miR-155 gátolja az mTOR-szignált, és elősegíti az autophagosoma-képződést, de a lysosomalis lebontás elmarad [48].

\section{Következtetések}

A májsejtekben az autophagia hozzájárul a sejtmúködés egyensúlyának fenntartásához, a káros hatások kivédéséhez, a szerv vagy szövet ép sejtjeinek túléléséhez. Védő hatású az alfa-1-antitripszin hiányában, alkoholos és nem alkoholos eredetű zsírmájban, és csökkent múködése hozzájárul a májkárosodás kialakulásához. A hepatitisvírusok a saját hasznukra fordítják az autophagiát, és felhasználják replikációjukhoz, a vírusfehérjék pedig szerepet játszanak az autophagia fokozásában.

A mikro-RNS-ek expressziójának megváltozása befolyásolja a májban az apoptózist, az autophagiát, az immunrendszer múködését, az anyagcsere-folyamatokat, és hatással van a gyulladásra, a kötőszövet-átépülésre, a májkárosodás kialakulására. A tumorok fejlődésének korai szakaszában gátolja a karcinogenezist. A későbbiekben azonban segíti a tumorok túlélését, hozzájárul a progresszióhoz.

Az autophagia és a mikro-RNS kapcsolatának, egymásra gyakorolt hatásának jobb megismerése közelebb visz a különböző májbetegségek kialakulásának megértéséhez, és segíthet hatékonyabb kezelési módok kifejlesztésében.

Anyagi támogatás: A közlemény megírása anyagi támogatásban nem részesült.

A szerző a cikk végleges változatát elolvasta és jóváhagyta.

Érdekeltségek: A szerzőnek nincsenek érdekeltségei.

\section{Irodalom}

[1] Asrani SK, Devarbhavi H, Eaton J, et al. Burden of liver diseases in the world. J Hepatol. 2019; 70: 151-171.

[2] Rautou PE, Mansouri A, Lebrec D, et al. Autophagy in liver disease. J Hepatol. 2010; 53: 1123-1134.

[3] Ueno T, Komatsu M. Autophagy in the liver: functions in health and disease. Nat Rev Gastroenterol Hepatol. 2017; 14: 170184.

[4] Werling K. Role of autophagy in the pathogenesis of liver diseases. [Az autophagia szerepe a májbetegségek kialakulásában.] Orv Hetil. 2011; 152: 1955-1961. [Hungarian]

[5] Czaja MJ. Functions of autophagy in hepatic and pancreatic physiology and disease. Gastroenterology 2011; 140: 18951908.

[6] Czaja MJ, Ding WX, Donohue TM Jr, et al. Functions of autophagy in normal and diseased liver. Autophagy 2013; 9: 11311158.

[7] Szekerczés T, Gógl A, Illyés I, et al. Autophagy, mitophagy and microRNA expression in chronic hepatitis $\mathrm{C}$ and autoimmune hepatitis. Pathol Oncol Res. 2020 Mar 2. Doi: 10.1007/ s12253-020-00799-y. [Online ahead of print]

[8] Czaja MJ. Autophagy in health and disease. 2. Regulation of lipid metabolism and storage by autophagy: pathophysiological implications. Am J Physiol Cell Physiol. 2010; 298: C973-C978.

[9] Fukuo Y, Yamashina S, Sonoue H, et al. Abnormality of autophagic function and cathepsin expression in the liver from pa- 
tients with non-alcoholic fatty liver disease. Hepatol Res. 2014; 44: 1026-1036

[10] Codogno P, Meijer AJ. Autophagy: a potential link between obesity and insulin resistance. Cell Metab. 2010; 11: 449-451.

[11] Taguchi K, Motohashi H, Yamamoto M. Molecular mechanisms of the Keap 1-Nrf2 pathway in stress response and cancer evolution. Genes Cells 2011; 16: 123-140.

[12] Hernández-Gea V, Ghiassi-Nejad Z, Rozenfeld R, et al. Autophagy releases lipid that promotes fibrogenesis by activated hepatic stellate cells in mice and in human tissue. Gastroenterology 2012; 142: 938-946.

[13] Ke PY, Chen SS. Autophagy: a novel guardian of HCV against innate immune response. Autophagy 2011; 7: 533-535.

[14] Rautou PE, Cazals-Hatem D, Feldmann G, et al. In vivo evidence of altered hepatocyte autophagic response in livers from patients with chronic hepatitis $\mathrm{C}$ virus infection. Hepatology 2009; 50: 943A.

[15] Vescovo T, Refolo G, Romagnoli A, et al. Autophagy in HCV infection: keeping fat and inflammation at bay. Biomed Res Int. 2014; 2014: 265353

[16] Sir D, Kuo CF, Tian Y, et al. Replication of hepatitis C virus RNA on autophagosomal membranes. J Biol Chem. 2012; 287: 18036-18043.

[17] Sir D, Tian Y, Chen WL, et al. The early autophagic pathway is activated by hepatitis B virus and required for viral DNA replication. Proc Natl Acad Sci USA 2010; 107: 4383-4388.

[18] Li J, Liu Y, Wang Z, et al. Subversion of cellular autophagy machinery by hepatitis B virus for viral envelopment. J Virol. 2011; 85: 6319-6333

[19] Eid N, Ito Y, Maemura K, et al. Elevated autophagic sequestration of mitochondria and lipid droplets in steatotic hepatocytes of chronic ethanol-treated rats: an immunhistochemical and electron microscopic study. J Mol Histol. 2013; 44: 311-326.

[20] Donohue TM Jr. Autophagy and ethanol-induced liver injury. World J Gastroenterol. 2009; 15: 1178-1185.

[21] Stoller JK, Aboussouan LS. A review of $\alpha \mathrm{l}$-antitrypsin deficiency. Am J Respir Crit Care Med. 2012; 185: 246-259.

[22] Mochida K, Oikawa Y, Kimura Y, et al. Receptor-mediated selective autophagy degrades the endoplasmic reticulum and the nucleus. Nature 2015; 522: 359-362.

[23] Li J, Pak SC, O'Reilly LP, et al. Fluphenazine reduces proteotoxicity in C. elegans and mammalian models of alpha-1-antitrypsin deficiency. PLoS ONE 2014; 9: e87260.

[24] Akkoç Y, Gözüaçık D. Autophagy and liver cancer. Turk J Gastroenterol. 2018; 29: 270-282.

[25] Sasaki M, Miyakoshi M, Sato Y, et al. Autophagy may precede cellular senescence of bile ductular cells in ductular reaction in primary biliary cirrhosis. Dig Dis Sci. 2012; 57: 660-666.

[26] Maiuri L, Kroemer G. Autophagy delays progression of the two most frequent human monogenetic lethal diseases: cystic fibrosis and Wilson disease. Aging (Albany NY) 2018; 10: 3657-3661.

[27] Szabó G, Bala S. MicroRNAs in liver disease. Nat Rev Gastroenterol Hepatol. 2013; 10: 542-552.

[28] Lendvai G, Kiss A, Kovalszky I, et al. Alterations in microRNA expression patterns in liver diseases. [Eltérések a májbetegségek mikro-RNS-expressziós mintázatában.] Orv Hetil. 2010; 151: 1843-1853. [Hungarian]

[29] Friedman RC, Farh KK, Burge CB, et al. Most mammalian mRNAs are conserved targets of microRNAs. Genome Res. 2009; 19: 92-105.

[30] Szabo G, Csak T. Role of microRNAs in NAFLD/NASH. Dig Dis Sci. 2016; 61: 1314-1324.
[31] Halász T, Horváth G, Pár G, et al. miR-122 negatively correlates with liver fibrosis as detected by histology and FibroScan. World J Gastroenterol. 2015; 21: 7814-7823.

[32] Lendvai G, Szekerczés T, Gyöngyösi B, et al. MicroRNA expression in focal nodular hyperplasia in comparison with cirrhosis and hepatocellular carcinoma. Pathol Oncol Res. 2019; 25: 11031109.

[33] Lanford RE, Hildebrandt-Eriksen ES, Petri A, et al. Therapeutic silencing of microRNA-122 in primates with chronic hepatitis C virus infection. Science 2010; 327: 198-201.

[34] Ura S, Honda M, Yamashita T, et al. Differential mircoRNA expression between hepatitis $\mathrm{B}$ and $\mathrm{C}$ leading disease progression to hepatocellular carcinoma. Hepatology 2009; 49: 1098-1112.

[35] Mahmoudian-Sani MR, Asgharzade S, Alghasi A, et al. MicroRNA-122 in patients with hepatitis B and hepatitis B virus-associated hepatocellular carcinoma. J Gastrointest Oncol. 2019; 10: 789-796

[36] Torres JL, Novo-Veleiro I, Manzanedo L, et al. Role of microRNAs in alcohol-induced liver disorders and non-alcoholic fatty liver disease. World J Gastroenterol. 2018; 24: 4104-4118.

[37] O'Neill LA, Sheedy FJ, McCoy CE. MicroRNAs: the fine-tuners of Toll-like receptor signalling. Nat Rev Immunol. 2011; 11: $163-175$.

[38] Momen-Heravi F, Saha B, Kodys K, et al. Increased number of circulating exosomes and their microRNA cargos are potential novel biomarkers in alcoholis hepatitis. J Transl Med. 2015; 13: 261.

[39] Wang Y, Yu D, Tolleson WH, et al. A systematic evaluation of microRNAs in regulating human hepatic CYP2E1. Biochem Pharmacol. 2017; 138: 174-184.

[40] Eslam M, Valenti L, Romeo S. Genetics and epigenetics of NAFLD and NASH: clinical impact. J Hepatol. 2018; 68: 268279.

[41] Pirola CJ, Fernández Gianotti T, Castaño GO, et al. Circulating microRNA signature in non-alcoholic fatty liver disease: from serum non-coding RNAs to liver histology and disease pathogenesis. Gut 2015; 64: 800-812.

[42] Gjorgjieva M, Sobolewski C, Dolicka D, et al. miRNAs and NAFLD: from pathophysiology to therapy. Gut 2019; 68: 20652079

[43] Gyöngyösi B, Végh E, Járay B, et al. Pretreatment microRNA level and outcome in sorafenib-treated hepatocellular carcinoma. J Histochem Cytochem. 2014; 62: 547-555.

[44] Erice O, Munoz-Garrido P, Vaquero J, et al. MicroRNA-506 promotes primary biliary cholangitis-like features in cholangiocytes and immune activation. Hepatology 2018; 67: 1420-1440.

[45] Tu H, Chen D, Cai C, et al. microRNA-143-3p attenuated development of hepatic fibrosis in autoimmune hepatitis through regulation of TAKl phosphorylation. J Cell Mol Med. 2020; 24: 1256-1267.

[46] Kim KM, Kim SG. Autophagy and microRNA dysregulation in liver diseases. Arch Pharm Res. 2014; 37: 1097-1116.

[47] Han W, Fu X, Xie J, et al. MiR-26a enhances autophagy to protect against ethanol-induced acute liver injury. J Mol Med (Berl). 2015; 93: 1045-1055.

[48] Babuta M, Furi I, Bala S, et al. Dysregulated autophagy and lysosome function are linked to exosome production by micro-RNA 155 in alcoholic liver disease. Hepatology 2019; 70: 2123-2141.

(Werling Klára dr., Budapest, Szentkirályi u. 46., 1088 e-mail: klara.werling@gmail.com)

A cikk a Creative Commons Attribution 4.0 International License (https://creativecommons.org/licenses/by/4.0/) feltételei szerint publikált Open Access közlemény, melynek szellemében a cikk bármilyen médiumban szabadon felhasználható, megosztható és újraközölhetö, feltéve, hogy az eredeti szerző és a közlés helye, illetve a CC License linkje és az esetlegesen végrehajtott módositások feltüntetésre kerülnek. (SID 1) 